\title{
Floating harbour syndrome with medial entropion: a rare association and brief review
}

\author{
Sahil Agrawal (D) ,' Saloni Gupta, ${ }^{2}$ Swechya Neupane, ${ }^{1}$ Deepsekhar Das (D) ${ }^{1}$
}

${ }^{1}$ Ophthalmology, Dr. Rajendra Prasad Centre for Ophthalmic Sciences, AllMS, Delhi, New Delhi, India

${ }^{2}$ Ophthalmology, Northern Railway Central Hospital New Delhi, New Delhi, Delhi, India

\section{Correspondence to} Dr Deepsekhar Das; doc.deep.das@gmail.com

SA and SG contributed equally.

Accepted 28 April 2021

Check for updates

(c) BMJ Publishing Group Limited 2021. No commercial re-use. See rights and permissions. Published by BMJ.

To cite: Agrawal S, Gupta S, Neupane $S$, et al. BMJ Case Rep 2021;14:e242125. doi:10.1136/bcr-2021242125

\section{DESCRIPTION}

A 6-year-old girl presented to us complaining of watering with associated frequent blinking in her both eyes since 2 years. There was history of delayed speech and delayed dentition. She was born out of consanguineous marriage; with no similar illness in any of her family members.

The child was alert, conscious with stable vitals. There was unusual dentition, large nose with an overhanging large columella, smooth philtrum and thin upper lips (figure 1A). On ophthalmological examination, best corrected visual acuity in both eyes was 6/6 and Intra ocular pressure (IOP) of $14 \mathrm{~mm} \mathrm{Hg}$. On further examination, bilateral epicanthal folds were seen along with medial entropion of both upper and lower eyelids with lashes touching the globes. The ocular surface was healthy; there was no epithelial defect or surface keratinisation (figure 1B). Fundus examination was within normal limits.

Routine blood investigations along with hormonal levels were within normal limits. Dental pantomogram showed absence of several teeth in lower jaw, indicating delayed dentition (figure 2). Diagnosis of floating harbour syndrome with bilateral medial entropion was made. She underwent bilateral Z-plasty for correction of medial entropion. Postoperative follow-up was unremarkable. A common differential diagnosis could be a medially localised epiblepharon of both lids. In case of an epiblepharon, on pulling the skin downwards, lashes should turn out with the lid still remains in apposition to the globe; however, this was not seen in our case.

The syndrome gets its name from the hospitals, Boston Floating Hospital and Harbour General Hospital where the first two cases were reported respectively by Pelletier and Feingold ${ }^{1}$ and Leisti et al. ${ }^{2}$ The condition is exceeding infrequent and until only around 65 cases of Floating Harbour Syndrome (FHS) have been reported. ${ }^{3}$ Most of the documented cases are sporadic in origin. Cases with family history of consanguinity have also been reported. ${ }^{4} \mathrm{~A}$ loss of the C-terminal portion of SRCAP protein, including the AT hook motifs have been implicated in the pathogenesis. ${ }^{3}$

Patients of FHS usually presents with delayed bone mineralisation and growth deficiency, often associated with mental retardation, skeletal and craniofacial abnormalities. ${ }^{3}$ Significant delay in bone age $(-2 \mathrm{SD})$ is a consistent feature in all patients. However, epiphysial closure takes place at puberty with normal endocrine studies of growth hormone, somatomedin $\mathrm{C}$ and thyroid function. ${ }^{4}$ Speech delay

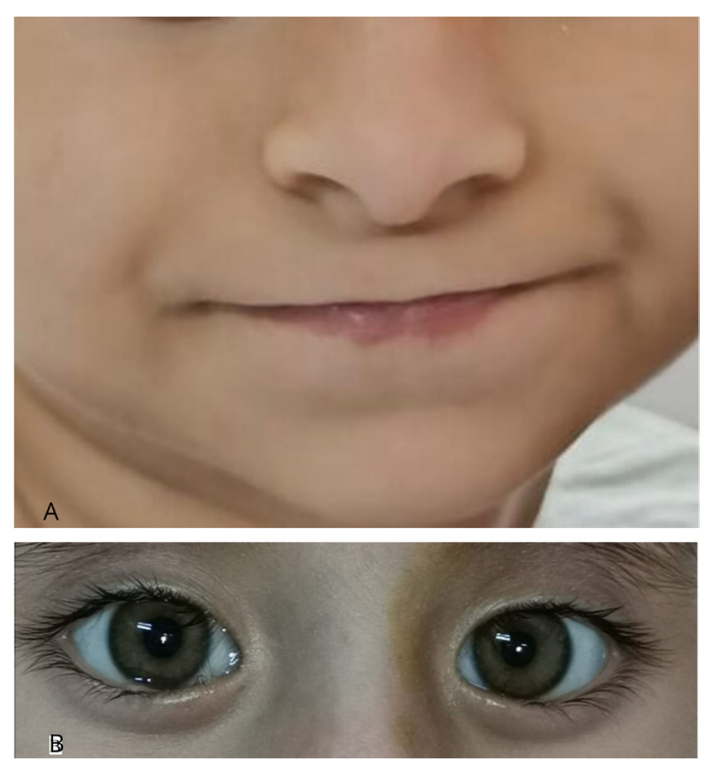

Figure 1 (A) Clinical picture of the patient showing triangular facies, prominent large nose with overhanging columella, smooth philtrum and thin upper lips. (B) Clinical picture showing bilateral upper and lower eyelid medial entropion with lashes touching the globe.

is a consistent feature of this syndrome. Striking facial features include broad and bulbous nose with a prominent nasal bridge and a wide columella with thin upper and lower lips; most recognisable during mid-childhood. The syndrome is also characterised by long lashes and dental malocclusion. There may be other associated features like clinodactyly of the fifth finger occasionally with a hypoplastic nail on that digit, accessory thumb, pulmonary stenosis and abnormal Electro Encephalogram (EEG). ${ }^{4}$

Nikkel et al gave the clinical features for coming to a diagnosis, which included mandatory features like: characteristic face and language delay, frequent features like: short stature, delayed bone age, skeletal anomalies and

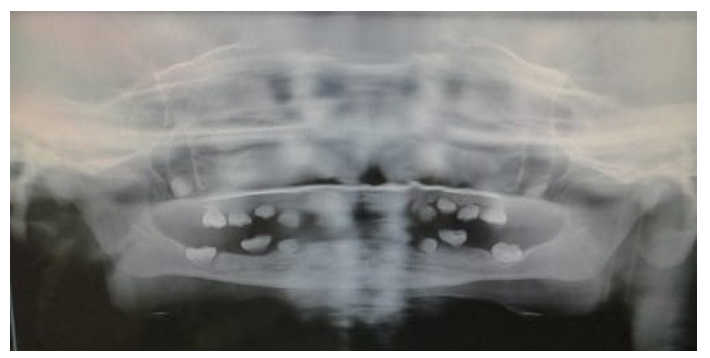

Figure 2 Dental pantomogram showing the absence of multiple teeth. 
intellectual disability, recurrent problems like: eye anomalies, ear anomalies and dental disorders, infrequent problems like: genitourinary malformations, cardiac malformations, gastrointestinal features, seizures and hypothyroidism. The presence of both mandatory criteria along with the presence of any one frequent feature confirms the clinical diagnosis. ${ }^{5}$ Ocular disorders reported with this condition include hyperopia, strabismus and nystagmus; however, entropion of eyelids has never been reported. ${ }^{67}$ The pathophysiology of the medial entropion could be a localised overaction of medial fibres of orbicularis muscle. It is may also possibly be a by chance association. We, here, document the first case of entropion in FHS.

\section{Patient's perspective}

Our child had eyelid problems with watering. We were relieved after the surgery as the doctor assured of no eye symptoms later and also a full body check-up assured us of no systemic complications.

\section{Learning points}

- Floating harbour syndrome is a rare entity. It is a triad of delayed bone age, abnormal speech and facial features.

- Although ocular features like strabismus, nystagmus and hyperopia have been previously documented with floating harbour syndrome; entropion can also be associated and is to be kept in mind when managing such a case.
Contributors DD and SA were the primary point of contact of patient and the operating surgeon. They also helped in critical revision of the article. SN helped in collecting data, clinical and radiological images of patient. SG drafted the article.

Funding The authors have not declared a specific grant for this research from any funding agency in the public, commercial or not-for-profit sectors.

Disclaimer Case reports provide a valuable learning resource for the scientific community and can indicate areas of interest for future research. They should not be used in isolation to guide treatment choices or public health policy.

Competing interests None declared.

Patient consent for publication Parental/guardian consent obtained.

Provenance and peer review Not commissioned; externally peer reviewed.

\section{ORCID iDs}

Sahil Agrawal http://orcid.org/0000-0001-6667-249X

Deepsekhar Das http://orcid.org/0000-0002-4446-0274

\section{REFERENCES}

1 Pelletier G, Feingold M. Case report 1. In: Bergsma D, ed. Syndrome identiftcation. White Plains, NY: National Foundation-March of Dimes, 1973: 8-9.

2 Leisti J, Hollister DW, Rimoin DL. Case report 2. In: Bergsma D, ed. Syndrome idenmfication. White Plains, NY: National Foundation-March of Dimes, 1974: 305.

3 Messina G, Atterrato MT, Dimitri P. When chromatin organisation floats astray: the SRCAP gene and Floating-Harbor syndrome. J Med Genet 2016;53:793-7.

4 Patton MA, Hurst J, Donnai D, et al. Floating-Harbor syndrome. J Med Genet 1991;28:201-4.

5 Nikkel SM, Dauber A, de Munnik S, et al. The phenotype of Floating-Harbor syndrome: clinical characterization of 52 individuals with mutations in exon 34 of SRCAP. Orphanet J Rare Dis 2013;8:63.

6 Hood RL, Lines MA, Nikkel SM, et al. Mutations in SRCAP, encoding SNF2-related CREBBP activator protein, cause Floating-Harbor syndrome. Am J Hum Genet 2012;90:308-13.

7 Le Goff C, Mahaut C, Bottani A, et al. Not all floating-harbor syndrome cases are due to mutations in exon 34 of SRCAP. Hum Mutat 2013;34:88-92.

Copyright 2021 BMJ Publishing Group. All rights reserved. For permission to reuse any of this content visit https://www.bmj.com/company/products-services/rights-and-licensing/permissions/

BMJ Case Report Fellows may re-use this article for personal use and teaching without any further permission.

Become a Fellow of BMJ Case Reports today and you can:

- Submit as many cases as you like

- Enjoy fast sympathetic peer review and rapid publication of accepted articles

- Access all the published articles

- Re-use any of the published material for personal use and teaching without further permission

Customer Service

If you have any further queries about your subscription, please contact our customer services team on +44 (0) 2071111105 or via email at support@bmj.com.

Visit casereports.bmj.com for more articles like this and to become a Fellow 